Ilyas, et al/Jurnal Ekonomi Syariah Teori dan Terapan Vol. 6 No. 9 September 2019: 1830-1839; PENGARUH INFLASI, NILAI TUKAR RUPIAH, BI RATE TERHADAP NILAI AKTIVA BERSIH REKSA DANA TERPROTEKSI SYARIAH PERIODE 2014-2018 DI INDONESIA

\title{
PENGARUH INFLASI, NILAI TUKAR RUPIAH, BI RATE TERHADAP NILAI AKTIVA BERSIH REKSA DANA TERPROTEKSI SYARIAH PERIODE 2014-2018 DI INDONESIA' ${ }^{1}$
}

\author{
Mohammad llyas \\ Departemen Ekonomi Syariah - Fakultas Ekonomi dan Bisnis - Universitas Airlangga \\ Email: mohammad.ilyas-2014@feb.unair.ac.id
}

\author{
Atina Shofawati \\ Departemen Ekonomi Syariah - Fakultas Ekonomi dan Bisnis - Universitas Airlangga \\ Email: atina-o@feb.unair.ac.id
}

\begin{abstract}
:
The Research aims to determine the influence of inflation, currency exchange rate, interest rate that affect net asset value of protected Islamic mutual fund from 2014-2018 in Indonesia partially and simultaneously. The research also uses quantitative approach and multiple regression analysis technique. The sample used for this research is obtained from monthly statistic data of Bank Indonesia, Otoritas Jasa Keuangan, and Pusat data kontan which had been published online from January 2014 to Desember 2018, so there are 60 samples taken for this reserch. The variabels of this research include inflation $\left(X_{1}\right)$, currency exchange rate $\left(X_{2}\right)$, interest rate $\left(X_{3}\right)$, and net asset value of protected Islamic mutual fund $(Y)$. The result of this research shows that partially, the inflation affect Net Asset Value of Protected Islamic Mutual Fund from 2014-2018 in Indonesia insignificantly, currency exchange rate affect Net Asset Value of Protected Islamic Mutual Fund from 2014-2018 in Indonesia significantly, and interest rate affect Net Asset Value of Protected Islamic Mutual Fund from 2014-2018 in Indonesia significantly. Simultaneously, all independent variables affect Net Asset Value of Protected Islamic Mutual Fund from 2014-2018 in Indonesia significantly.
\end{abstract}

Keywords: Macroeconomic, Inflation, InterestRate, Currency Exchange Rate, Net Asset Value, Protected Islamic Mutual Fund

\section{PENDAHULUAN}

\section{Latar Belakang}

Kevangan Syariah sedang berkembang untuk meraih identitas global. Saat ini keuangan Syariah sudah mengembangkan produk Syariah di pasar modal. Pasar modal Syariah merupakan salah satu komponen penting yang sedang berkembang dalam keuangan Syariah sebagai penunjang perbankan Syariah, asuransi Syariah, dan lembaga keuangan Syariah lainnya. Perkembangan pasar modal Syariah dapat dilihat dari perkembangan produk Syariah seperti saham Syariah, sukuk dan reksadana Syariah.

Pasar modal adalah pasar yang mempertemukan mereka yang memerlukan dana jangka panjang dan mereka yang dapat menyediakan dana tersebut. Jual beli dana jangka panjang ditunjukkan dengan kegiatan perusahaan yang menerbitkan saham, obligasi dan sekuritas-sekuritas lain yang bersifat jangka panjang. Bursa efek merupakan satu bentuk kegiatan pasar modal (Rahmawati, 2009).

\footnotetext{
${ }^{1}$ Jurnal ini adalah bagian dari skrispi Mohammad llyas, NIM: 041411433017, yang diuji pada tanggal 24 September 2019.
} 
Ilyas, et al/Jurnal Ekonomi Syariah Teori dan Terapan Vol. 6 No. 9 September 2019: 1830-1839; PENGARUH INFLASI, NILAI TUKAR RUPIAH, BI RATE TERHADAP NILAI AKTIVA BERSIH REKSA DANA TERPROTEKSI SYARIAH PERIODE 2014-2018 DI INDONESIA

Dengan adanya pasar modal berbasis Syariah di Indonesia diharapkan dapat membantu bank dan asuransi Syariah mengoptimalkan penggunaan sumber dana yang tersedia sesuai dengan prinsip Syariah selagi menjaga keseimbangan antara likuiditas dan tingkat keuntungan. Selain itu, kehadiran produk Syariah di pasar modal Indonesia membuka peluang berinvestasi bagi masyarakat yang meyakini bahwa produk investasi konvensional mengandung komponen yang diharamkan Syariah antara lain mengandung unsur maysir, gharar, dan riba.

Keberadaan reksadana di Indonesia dapat dikatakan telah dimulai pada saat diaktifkannya kembali pasar modal di Indonesia. Pada saat itu, penerbitan reksadana dilakukan oleh persero (BUMN) yang didirikan khusus untuk menunjang kegiatan pasar modal Indonesia, sekalipun pada saat itu belum ada pengaturan khusus mengenai reksadana. Istilah reksadana lebih dikenal pada tahun 1990 dengan diizinkaannya pelaku pasar modal untuk menerbitkan reksadana melalui keppres No. 53 Tahun 1990 tentang Pasar Modal. Pada tahun 1997 yang diawali dengan krisis ekonomi di Indonesia. Kemacetan bank dalam menjalankan fungsi intermediasi berdampak cukup besar dalam memacetkan perekonomian secara keseluruhan (Zakariya, 2017).

Reksa dana terproteksi Syariah mempunyai sifat yang terbatas, maksudnya adalah bahwa reksa dana ini hanya bisa dibeli dalam jangka waktu dan nominal tertentu. Ketika mendapatkan pernyataan efektif, manajer investasi akan membuka masa penawaran reksa dana yang lamanya bisa berkisar antara 1 sampai 3 bulan. Salah satu ciri dari reksa dana terproteksi Syariah adalah underlyingreksa dana akan ditahan sampai jatuh tempo, hal ini sangat berbeda dengan produk reksa dana pendapatan tetap yang akan memperdagangkan underlying reksa dana tersebut. Karena perbedaan cara penanganan dalam underlying reksa dana, maka reksa dana terproteksi Syariah hanya bisa dibeli pada saat di awal saja dan tidak bisa dijual sebelum masa jatuh tempo. Sementara jika pada reksa dana pendapatan tetap, investor dapat melakukan pembelian dan penjualan underlyingreksa dana kapan saja (Rudiyanto, 2011).

Penelitian ini menjadi menarik mengingat belum banyak yang meneliti tentang reksa dana terproteksi Syariah, meskipun banyak yang meneliti pengaruh variabel makro ekonomi terhadap reksa dana Syariah. Peneliti terdahulu yang meneliti tentang reksa dana terproteksi Syariah hanya melihat kinerja yaitu penelitian oleh Maditiara (2018) yang berjudul Perbandingan Kinerja Reksadana Terproteksi Syariah dengan Metode Indeks Sharpe, Treynor, dan Jensen (Periode 2013-2016). Maka dari itu penulis termotivasi untuk meneliti reksa dana 
Ilyas, et al/Jurnal Ekonomi Syariah Teori dan Terapan Vol. 6 No. 9 September 2019: 1830-1839; PENGARUH INFLASI, NILAI TUKAR RUPIAH, BI RATE TERHADAP NILAI AKTIVA BERSIH REKSA DANA TERPROTEKSI SYARIAH PERIODE 2014-2018 DI INDONESIA

terproteksi Syariah dikarenakan masih kurangnya penelitian terhadap reksa dana tersebut.

\section{Rumusan Masalah}

1. Apakah inflasi berpengaruh signifikan secara parsial terhadap nilai aktiva bersih reksadana terproteksi Syariah periode 2014-2018 di Indonesia?

2. Apakah nilai tukar Rupiah berpengaruh signifikan secara parsial terhadap nilai aktiva bersih reksadana terproteksi Syariah periode 2014-2018 di Indonesia?

3. Apakah Bl rate berpengaruh signifikan secara parsial terhadap nilai aktiva bersih reksadana terproteksi Syariah periode 2014-2018di Indonesia?

4. Apakah Inflasi, nilai tukar Rupiah, BI rate berpengaruh signifikan secara simultan terhadap nilai aktiva bersih reksa dana terproteksi Syariah periode 2014-2018 di Indonesia?

\section{LANDASAN TEORI}

\section{Reksa Dana Syariah}

Reksa dana merupakan suatu instrumen keuangan untuk menghimpun dana dari masyarakat pemodal secara kolektif. Dana yang terkumpul ini, selanjutnya dikelola dan diinvestasikan oleh seorang manajer investasi (fundmanager) melalui saham, obligasi, valuta asing atau deposito (Farid, 2014).

Reksa dana berasal dari dua kata yaitu reksa yang berarti penjaga dan dana yang berarti uang yang disediakan untuk suatu keperluan atau biaya, Sedangkan syariat yang berasal dari bahasa Arab adalah Syariah artinya yaitu hukum agama yang menetapkan peraturan hidup manusia dan hubungannya dengan Allah, sesama manusia, dan alam sekitar berdasarkan AlQur'an dan Hadist. Reksa dana pada ranah internasional mempunyai nama lain yaitu Unit Trust atau Mutual Fund dan atau Investment Fund adalah suatu wadah yang berfungsi untuk menghimpun dana para investor untuk diinvestasikan dalam portofolio efek oleh manajer investasi yang mendapat izin dari Otoritas Jasa Keuangan (OJK) yang pada awalnya adalah Badan Pengawas Pasar Modal (Bapepam) (Farid, 2014).

Menurut Fatwa Dewan Syariah Nasional No.20/DSN-MUI/IX/2000, reksa dana Syariah adalah reksa dana yang beroperasi menurut ketentuan dan prinsip Syariah Islam, baik dalam bentuk akad antara pemodal sebagai pemilik harta (shabal-mal/raib al-mal) dengan manajer investasi sebagai wakil sahibal-mal, maupun antara manajer investasi sebagai wakil sahibal-maldengan pengguna investasi. Sedangkan menurut Susanto (2008:74), menjelaskan bahwa reksa dana Syariah merupakan salah satu lembaga kevangan yang dapat dijadikan alternatif berinvestasi bagi masyarakat yang menginginkan return dari sumber yang bersih dan dapat dipertanggungjawabkan secara Syariah. Tujuan utama reksa dana Syariah bukan semata-mata hanya mencari keuntungan, tetapi juga memiliki 
Ilyas, et al/Jurnal Ekonomi Syariah Teori dan Terapan Vol. 6 No. 9 September 2019: 1830-1839; PENGARUH INFLASI, NILAI TUKAR RUPIAH, BI RATE TERHADAP NILAI AKTIVA BERSIH REKSA DANA TERPROTEKSI SYARIAH PERIODE 2014-2018 DI INDONESIA

tanggung jawab sosial terhadap lingkungan, komitmen pada nilai-nilai religius, meskipun tanpa harus mengabaikan kepentingan para investor.

\section{Nilai Aktiva Bersih}

Nilai Aktiva Bersih (NAB) atau sering juga disebut sebagai Net Asset Value(NAV) merupakan alat ukur kinerja reksa dana. Nilai aktiva bersih berasal dari nilai portofolio reksa dana yang bersangkutan. Nilai Aktiva Bersih (NAB) juga merupakan jumlah aktiva setelah dikurangi kewajiban-kewajiban yang ada. Sedangkan NAB per Unit Penyerta merupakan jumlah NAB dibagi dengan jumlah nilai Unit Penyerta yang beredar (outstanding) yang telah beredar (dimiliki Investor) pada saat tertentu (Sudarsono, 2007).

$N A B$ per saham/unit dihitung setiap hari oleh Bank Kustodiansetelah mendapat dana dari Manajer Investasi dan nilainya dapat dilihat dari surat kabar yang dilihat reksa dana bersangkutan setiap hari. Besarnya NAB bisa berfluktuasi setiap harinya, tergantung dari perubahan nilai efek portofolio. Meningkatnya NAB mengindikasikan naiknya nilai investasi pemegang saham/unit penyertaan. Begitu juga sebaliknya, jika menurun berarti berkurang nilai investasi pemegang unit penyerta (Achsien, 2000).

\section{Inflasi}

Pada ilmu ekonomi, inflasi merupakan suatu proses meningkatnya harga-harga secara umum dan terus menerus berkaitan dengan mekanisme pasar yang dapat disebabkan oleh berbagai faktor, yaitu konsumsi masyarakat yang meningkat, berlebihnya likuiditas di pasar yang memicu konsumsi atau spekulasi, termasuk akibat ketidaklancaran distribusi barang. Dengan kata lain, inflasi dapat diartikan sebagai proses menurunnya nilai mata uang secara terus menerus. Kenaikan harga dari satu atau dua barang saja tidak dapat disebut inflasi kecuali kenaikan itu meluas (atau mengakibatkan kenaikan harga) pada barang lainnya. Kenaikan inflasi akan menyebabkan harga barang maupun jasa meningkat sehingga menurunkan laba perusahaan. Akibatnya menurunkan bagi hasil yang akan di bagikan kepada investor, sehingga investasi di anggap sebagai hal yang tidak menarik karena tidak dapat memberikan keuntungan yang di harapkan (Nandari, 2017). Kemudian harga saham juga akan turun dengan diikuti menurunnya Nilai Aktiva Bersih (NAB).

Inflasi memiliki dampak positif dan dampak negatif tergantung dari parah atau tidaknya tingkat inflasi itu sendiri. Menurut SadonoSukirno(2002:16), sebagian ahli ekonomi berpendapat bahwa inflasi yang sangat lambat berlakunya dipandang sebagai stimulator bagi pertumbuhan ekonomi. Inflasi yang ringan justru memiliki pengaruh yang positif dalam kata lain mendorong perekonomian lebih baik, yaitu 
Ilyas, et al/Jurnal Ekonomi Syariah Teori dan Terapan Vol. 6 No. 9 September 2019: 1830-1839; PENGARUH INFLASI, NILAI TUKAR RUPIAH, BI RATE TERHADAP NILAI AKTIVA BERSIH REKSA DANA TERPROTEKSI SYARIAH PERIODE 2014-2018 DI INDONESIA

meningkatkan pendapatan nasional dan membuat orang giat untuk bekerja, menabung, dan berinvestasi. Kenaikan harga dalam inflasi yang tergolong rendah tersebut tidak secepatnya diikuti oleh kenaikan upah pekerja, sehingga keuntungan akan bertambah. Pertambahan keuntungan akan menggalakkan investasi dimasa datang dan ini akan mewujudkan percepatan dalam pertumbuhan ekonomi. Berbeda halnya dengan inflasi ringan, dalam masa inflasi yang parah, yaitu pada saat terjadi inflasi tak terkendali atau hiper inflasi, juga menimbulkan beberapa akibat buruk kepada individu, masyarakat, dan kegiatan perekonomian secara keseluruhan. Ketiadaan pertumbuhan ekonomi sebagai akibat dari inflasi yang serius menyebabkan perekonomian menjadi kacau dan perekonomian dirasakan tidak bergairah, orang menjadi tidak bersemangat bekerja, menabung, atau mengadakan investasi dan produksi karena harga meningkat dengan cepat (Sukirno, 2002:16).

\section{Nilai Tukar Rupiah}

Menurut SadonoSukirno (2002:178) nilai tukar rupiah (kurs) adalah harga mata vang suatu negara terhadap negara lain, nilai tukar merupakan variabel makro ekonomi yang turut mempengaruhi validitas harga saham. Hal ini disebabkan karena nilai kurs yang tidak stabil dianggap dapat berimbas pada faktor produksi perusahaan. Menurunnya kurs mata vang rupiah ternyata tidak selalu membawa dampak negatif bagi sektorsektor ekonomi di Indonesia. Nilai mata vang rupiah yang terus berfluktuasi tentunya sangat berdampak terhadap perekonomian Indonesia, baik positif maupun negatifnya. Salah satu dampak negatifnya yaitu jika nilai tukar menurun maka biaya produksi akan meningkat dan hutang perusahaan akan meningkat, sehingga bagi hasil yang diberikan pun akan menurun, hal tersebut menyebabkan investasi tidak lagi menarik bagi investor, sehingga menurunkan nilai investasi yang berdampak pada menurunnya Nilai Aktiva Bersih (NAB) suatu reksa dana (Nandari, 2017).

\section{BI Rate}

Menurut Dahlan Siamat (2005) BI Rate adalah suku bunga dengan tenor satu bulan yang diumumkan oleh Bank Indonesia secara periodik untuk jangka waktu tertentu yang berfungsi sebagai sinyal (stance) kebijakan moneter. BI Rate akan berpengaruh pada tingkat suku bunga yang merupakan pembayaran bunga tahunan dari suatu pinjaman, dalam bentuk persentase pinjaman yang di peroleh dari jumlah bunga yang diterima tiap tahun dibagi dengan jumlah pinjaman. Akibatnya jika BI Rate naik maka pengembalian terhadap pinjaman yang dilakukan emiten juga akan mengalami kenaikan, dan return yang di bagi akan mengalami penurunan, sehingga nilai aktiva bersih suatu Reksa dana juga akan mengalami penurunan (Karl, 2001:52). 
Ilyas, et al/Jurnal Ekonomi Syariah Teori dan Terapan Vol. 6 No. 9 September 2019: 1830-1839; PENGARUH INFLASI, NILAI TUKAR RUPIAH, BI RATE TERHADAP NILAI AKTIVA BERSIH REKSA DANA TERPROTEKSI SYARIAH PERIODE 2014-2018 DI INDONESIA

\section{METODE PENELITIAN}

Pendekatan yang digunakan dalam penelitian ini adalah metode kuantitatif. Metode kuantitatif adalah metode penelitian yang berdasarkan filsafat positivisme, digunakan untuk meneliti populasi atau sampel tertentu, pengumpulan data menggunakan instrumen penelitian, analisis data bersifat kuantitatif atau statistik, dengan tujuan untuk menguji hipotesis yang telah ditetapkan. Data yang terkumpul akan dilakukan pengujian secara kuantitatif dengan menggunakan statistik deskriptif atau inferensial sehingga dapat disimpulkan hipotesis yang disimpulkan terbukti atau tidak (Sugiyono, 2011). Penelitian ini menggunakan pendekatan kuantitatif yang bertujuan untuk menguji hipotesis, dengan data yang terukur dan menghasilkan kesimpulan yang dapat digeneralisir.

Berdasarkan dari permasalahan dan hipotesis maka variabel-variabel yang digunakan dalam penelitian ini dapat diidentifikasikan menjadi dua variabel, yaitu:

a. Variabel independen (X), yaitu inflasi, nilai tukar rupiah, dan $\mathrm{BI}$ rate.

b. Variabel dependen (Y), yaitu Nilai Aktiva Bersih (NAB) reksa dana terproteksi Syariah.

$Y=a+\beta_{1} X_{1}+\beta_{2} X_{2}+\beta_{3} X_{3}+e$ (3.4)

Keterangan :

Y $=$ Nilai aktiva bersih reksa dana Syariah

$$
\begin{aligned}
& \text { a } \quad=\text { Konstanta } \\
& \mathrm{X} 1 \quad=\text { Inflasi } \\
& \mathrm{X} 2=\mathrm{B} \text { rate } \\
& \text { X3 = Nilai tukar Rupiah }
\end{aligned}
$$

$\beta_{1}, \beta_{2}, \beta_{3}=$ Koefisien regresi

$$
\text { e } \quad=\quad \text { error(variabel }
$$$$
\text { pengganggu) }
$$

\section{DEFINISI OPERASIONAL}

Inflasi $\left(\mathrm{X}_{1}\right)$

Inflasi adalah kecenderungan harga-harga untuk naik secara umum dan terus menerus (Mankiw, 2006). Data inflasi merupakan data nasional yang secara bulanan yang dipublikasikan oleh Bank Indonesia periode Januari 2014 sampai Desember 2018. Angka inflasi diperoleh dengan menggunakan rumus perhitungan di bawah ini:

Inflasi $\left.(I \mathrm{HK})=\frac{I H K_{t}-I H K_{t-1}}{I H K_{t-1}} \times 100 \%\right)$

Keterangan:

$\mathrm{HHK}_{\dagger}=$ Indeks Harga Konsumen pada periode $\dagger$

$\mathrm{HHK}_{\mathrm{t}-\mathrm{l}}=$ Indeks Harga Konsumen pada periode sebelum $t$.

\section{Nilai Tukar Rupiah $\left(\mathrm{X}_{2}\right)$}

Nilai tukar rupiah didefinisikan sebagai harga mata vang negara lain (Pilbeam, 2006:72). Data nilai tukar Rupiah merupakan data nilai kurs tengah Rupiah terhadap Dollar AS secara bulanan yang dipublikasikan oleh Bank Indonesia periode Januari 2014 sampai Desember 2018. Nilai kurs tengah diperoleh dengan menggunakan rumus di bawah ini:

Kurs Tengah $=\frac{\text { Kurs Jual-Kurs Beli }}{2}$

\section{BI Rate $\left(X_{3}\right)$}


Ilyas, et al/Jurnal Ekonomi Syariah Teori dan Terapan Vol. 6 No. 9 September 2019: 1830-1839; PENGARUH INFLASI, NILAI TUKAR RUPIAH, BI RATE TERHADAP NILAI AKTIVA BERSIH REKSA DANA TERPROTEKSI SYARIAH PERIODE 2014-2018 DI INDONESIA

Menurut Karl (2001), suku bunga adalah pembayaran bunga tahunan dari suatu pinjaman, dalam bentuk persentase dari pinjaman yang diperoleh dari jumlah bunga yang diterima tiap tahun dibagi dengan jumlah pinjaman. Data BI Rate ini diperoleh dari situs resmi Bank Indonesia periode Januari 2014 sampai Desember 2018.

\section{Variabel Terikat (Y)}

Nilai Aktiva Bersih

(NAB)

merupakan nilai aktiva reksa dana setelah dikurangi nilai kewajiban reksa dana tersebut. Nilai Aktiva Bersih (NAB) reksa dana terproteksi Syariah diambil dari data Nilai Aktiva Bersih (NAB) reksa dana terproteksi secara bulanan yang dikeluarkan oleh pusat data kontan sejak Januari 2014 sampai dengan Desember 2018 dalam bentuk rupiah. Total nilai aktiva bersih diperoleh dengan menggunakan rumus di bawah ini"

Total NAB = Nilai Aktiva - Total Kewajiban

Populasi dan Sampel

Prasetyo dan Lina

menjelaskan pengertian populasi adalah keseluruhan gejala atau satuan yang ingin diteliti. Populasi pada penelitian ini adalah 42 reksa dana terproteksi Syariah yang terdaftar di OJK. Anshori dan Iswati (2009) menjelaskan bahwa sampel adalah bagian dari jumlah dan karakteristik yang dimiliki oleh populasi. Metode pemilihan sampel yang digunakan dalam penelitian ini adalah puposive sampling, yaitu pengambilan sampel yang menyesuaikan diri dengan kriteria tertentu. Pada teknik ini unsur populasi yang ditentukan menjadi sampel didasarkan pada tujuan penelitian. Puposive sampling adalah penarikan sampel dengan pertimbangan tertentu. Pertimbangan tersebut didasarkan pada kepentingan atau tujuan penelitian (Suharyadi dan Purwanto, 2004:332).

Pertimbangan tersebut didasarkan pada kepentingan atau tujuan penelitian. Jadi, penulis tidak mengambil semua produk reksa dana sebagai subjek penulisan tetapi hanya yang memenuhi syaratsyarat sebagai berikut:

1. Sampel yang diambil merupakan Reksa dana Terproteksi Syariah yang terdaftar di OJK.

2. Reksa dana terproteksi Syariah yang selama periode penelitian (2014-2018) tidak bubar, tidak merger, dan tercatat di OJK.

3. Sampel yang diambil merupakan produk dari perusahaan reksa dana terproteksi Syariah yang Nilai Aktiva Bersih (NAB) dipublikasikan di media cetak.

Dari syarat tersebut penulis memilih sampel produk reksa dana terproteksi Syariah yang memenuhi kriteria tersebut yaitu Syariah mandiri protecteddynamic Syariah seri 3 dari sebanyak 42 data yang digunakan.

\section{HASIL DAN PEMBAHASAN}

Hasil Uji $F$ 
llyas, et al/Jurnal Ekonomi Syariah Teori dan Terapan Vol. 6 No. 9 September 2019: 1830-1839; PENGARUH INFLASI, NILAI TUKAR RUPIAH, BI RATE TERHADAP NILAI AKTIVA BERSIH REKSA DANA TERPROTEKSI SYARIAH PERIODE 2014-2018 DI INDONESIA

\begin{tabular}{|c|c|c|c|c|c|c|}
\hline \multicolumn{2}{|c|}{ Model } & $\begin{array}{l}\text { Sum of } \\
\text { Squares }\end{array}$ & df & $\begin{array}{l}\text { Mean } \\
\text { Square }\end{array}$ & F & Sig, \\
\hline \multirow[t]{3}{*}{1} & $\begin{array}{l}\text { Regres } \\
\text { sion }\end{array}$ & 68,044 & 3 & 22,681 & 33,996 &, $000^{b}$ \\
\hline & $\begin{array}{l}\text { Residu } \\
\text { al }\end{array}$ & 37,362 & 56 & ,667 & & \\
\hline & Total & 105,405 & 59 & & & \\
\hline
\end{tabular}

a. Dependent Variable: Nilai Aktiva Bersih

b. Predictors: (Constant), Nilai Tukar Rupiah, BI Rate, Inflasi

Berdasarkan Tabel hasil uji F di atas, diperoleh nilai $F$ hitung sebesar 33,996 dengan nilai signifikan 0,000. F Tabel dengan Df penyebut sebesar 56 dan pembilang sebesar 3 menunjukkan angka 2,77 maka hal ini menyimpulkan bahwa $\mathrm{F}$ hitung $>$ F Tabel $(33,996>2,77)$. Tingkat signifikansi $F$ hitung lebih kecil jika dibandingkan dengan tingkat signifikansi yang telah ditentukan yaitu 0,05 maka dapat disimpulkan bahwa variabel inflasi, $\mathrm{BI}$ rate, dan nilai tukar Rupiah, berpengaruh signifikan secara simultan terhadap nilai aktiva bersih reksa dana terproteksi Syariah.

\section{Hasil Uji T}

\begin{tabular}{|ll|r|r|}
\hline & & \multicolumn{1}{c|}{$\mathrm{t}$} & Sig. \\
\hline 1 & (Constant) & 464,569 &, 000 \\
& Inflasi & $-1,044$ &, 301 \\
& BI Rate & $-2,026$ &, 047 \\
& Nilai Tukar Rupiah & 5,888 &, 000 \\
\hline
\end{tabular}

a. Dependent Variable: Nilai Aktiva Bersih|

Berdasarkan Tabel di atas, maka pengujian terhadap hipotesis pengaruh masing-masing variabel independen terhadap variabel dependen dapat dijelaskan sebagai berikut:

1. Variabel inflasi memiliki t hitung sebesar -1,044 dengan signifikansi sebesar 0,301. Nilai signifikansi lebih besar dari derajat kesalahan yang telah ditentukan sebesar 0,05 $(0,301>0,05)$ maka dapat ditarik kesimpulan bahwa secara parsial variabel inflasi berpengaruh tidak signifikan terhadap nilai aktiva bersih reksa dana terproteksi Syariah.

2. Variabel BI rate memiliki t hitung $-2,026$ dengan signifikansi sebesar 0,047 . Nilai signifikansi lebih kecil dari derajat kesalahan yang telah ditentukan sebesar $0,05(0,47<0,05)$ maka dapat ditarik kesimpulan bahwa secara parsial variabel $\mathrm{BI}$ rate berpengaruh signifikan terhadap nilai aktiva bersih reksa dana terproteksi Syariah.

3. Variabel nilai tukar Rupiah memiliki $\dagger$ hitung sebesar 5,888 dengan signifikansi 0,000 . Nilai signifikansi lebih kecil dari derajat kesalahan yang telah ditentukan sebesar 0,05 $(0,000<0,05)$ maka dapat ditarik kesimpulan bahwa secara parsial variabel nilai tukar Rupiah berpengaruh signifikan terhadap nilai aktiva bersihreksa dana terproteksi Syariah.

\section{SIMPULAN dan SARAN}

\section{Simpulan}

Berdasarkan hasil analisis dan pembahasan pada bab sebelumnya, maka dapat disimpulkan sebagai berikut:

1. Inflasi secara parsial berpengaruh tidak signifikan terhadap nilai aktiva bersih reksa dana terproteksi Syariah di Indonesia.

2. BI ratesecara parsial berpengaruh signifikan terhadap nilai aktiva bersih reksa dana Syariah di Indonesia. 
Ilyas, et al/Jurnal Ekonomi Syariah Teori dan Terapan Vol. 6 No. 9 September 2019: 1830-1839; PENGARUH INFLASI, NILAI TUKAR RUPIAH, BI RATE TERHADAP NILAI AKTIVA BERSIH REKSA DANA TERPROTEKSI SYARIAH PERIODE 2014-2018 DI INDONESIA

3. Nilai tukar Rupiah secara parsial berpengaruh signifikan terhadap nilai aktiva bersih reksa dana terproteksi Syariah di Indonesia.

4. Inflasi, BI rate, dan nilai tukar rupiah secara simultan berpengaruh signifikan terhadap nilai aktiva bersih reksa dana Syariah di Indonesia.

\section{Saran}

Berdasarkan simpulan tersebut, saran yang disampaikan dalam penelitian ini adalah:

1. Bagi pemerintah dalam hal ini Bank Indonesia sebagai regulator moneter, maka diharapkan agar tetap menjaga kestabilan moneter mengingat indikator moneter khususnya BI ratedan nilai tukar Rupiah yang memiliki pengaruh yang cukup besar terhadap NAB reksa dana Syariah serta terus berupaya menerapkan kebijakan yang dapat menstimulus perkembangan investasi di Indonesia terutama investasi berbasis Syariah seperti reksa dana terproteksi Syariah.

2. Bagi masyarakat yang hendak melakukan investasi di reksa dana Syariah hendaknya mempertimbangkan faktor makro ekonomi terutama BI ratedan nilai tukar Rupiah karena kedua variabel tersebut berpengaruh signifikan terhadap nilai aktiva bersih reksa dana terproteksi Syariah.

3. Bagi peneliti selanjutnya dapat melanjutkan penelitian ini dengan obyek penelitian bukan dari nilai aktiva bersih reksa dana terproteksi Syariah tetapi bisa mengambil reksa dana Syariah jenis yang lain.

\section{DAFTAR PUSTAKA}

Achsien, Iggi H. 2000. Investasi Syariah di Pasar Modal, Menggagas konsep dan Praktek portofolio Syariah. Jakarta: Gramedia Pustaka Utama. Anshori, Muslich, Sri Iswati. 2009. Metode Penelitian Kuantitatif. Cetakan Pertama. Surabaya: Universitas Airlangga press.

Farid, Muhammad. 2014. Mekanisme dan

$$
\begin{aligned}
& \text { Perkembangan Reksadana } \\
& \text { Syariah.lqtishoduna Vol. } 4 \text { No. } 1 . \\
& \text { HIm. 61-72. }
\end{aligned}
$$

Karl, E. Case, dan Fair, C. Rai. 2001. PrinsipPrinsip Ekonomi Makro. Jakarta: Prenhalindo.

Mankiw, Gregory. 2006. Pengantar Ekonomi Makro. Edisi Ketiga. Jakarta: Salemba Empat.

Nandari, Herlina Utami Dwi Ratna Ayu. 20017. Pengaruh Inflasi, Kurs dan $B I$ Rate Terhadap Nilai Aktiva Bersih (NAB) Reksadana Syariah di Indonesia (Periode 2010-2016). AnNisba Vol. 04 No. 01. HIm. 52-73.

Pilbeam, Keith. 2006. International Finance.3rd Edition. New York.

Prasetyo, Bambang dan Lina MiftahulJannah. 2012. Metode Penelitian Kuantitatif. Jakarta: PT. Raja Grafindo Persada.

Rahmawati, Yuke. 2009. Resolusi Investasi Kevangan Syariah. Jurnal Allqtishad Vol. 1 No. 1. HIm. 65-78. 
Ilyas, et al/Jurnal Ekonomi Syariah Teori dan Terapan Vol. 6 No. 9 September 2019: 1830-1839; PENGARUH INFLASI, NILAI TUKAR RUPIAH, BI RATE TERHADAP NILAI AKTIVA BERSIH REKSA DANA TERPROTEKSI SYARIAH PERIODE 2014-2018 DI INDONESIA

Rudiyanto. 2011. Reksa Dana untuk

Pemula. Jakarta: Elex media

Komputindo

Sudarsono, Heri. 2007. Bank dan Lembaga Keuangan Syariah (Deskripsi dan Ilustrasi). Edisi Kedua. Yogyakarta: Ekonisia.

Sugiyono. 2011. Metode Penelitian Kuantitatif, Kualitatif dan R\&D. Edisi Kedua Belas. Bandung: Alfabeta.

Suharyadi dan Purwanto, S. K. 2004. Statistika Dasar. Jakarta: Salemba Empat.
Sukirno, Sadono. 2002. Pengantar Teori Makro Ekonomi. Edisi Kedua. Jakarta: PT Raja Grafindo Persada.

Sukirno, Sadono. 2006. Makro Ekonomi Teori Pengantar. Edisi Ketiga. Jakarta: PT Raja Grafindo Persada.

Susanto, Burhanuddin. 2008. Hukum Perbankan Syariah di Indonesia. UII Press. Yogyakarta.

Zakariya, Mukhamad. 2017. Pertumbuhan Lembaga ReksadanaSyariah di Indonesia. JES Vol. 1 No. 2. HIm.276285. 